\title{
ASSESSMENT MODEL FOR EFFECTIVE SCHOOLS
}

\author{
Heru Budi Utomo ${ }^{1}$, Faridl Musyadad ${ }^{2}$ and Dwi Yunanto ${ }^{3}$ \\ ${ }^{1}$ PT. Media Sinar Utama, Purworejo, Jawa Tengah, Indonesia \\ ${ }^{2}$ IKIP PGRI, Wates, Yogyakarta, Indonesia \\ ${ }^{3}$ PPPPTK Seni dan Budaya, Yogyakarta, Indonesia \\ ${ }^{1}$ herubjk@gmail.com, ${ }^{2}$ faridl.musyadad@gmail.com, ${ }^{3}$ dwiyunanto71@gmail.com
}

\begin{abstract}
General objective of this study was to Assessment model for effective schools consisting of instruments and implementation guidance in order to make an assessment and self-improvement school (self-evaluation and self-improvement), as well as increased effectiveness school management functions so that schools are able to produce quality graduates who are expected. The specific objective of activities to develop (1) construct and effective school indicators, (2) a set of effective school assessment instruments, (3) an effective system of school assessment and implementation guidance. This model of development is closely linked to improving the quality of education in schools. Therefore, an indicator of the development of the model is learning, management and school climate, Guidance and Counseling, Student and extra-curricular activities, and the partnership school with the community.
\end{abstract}

\section{Keywords- Effective; Schools; Assessment model}

\section{INTRODUCTION}

The advantages of a nation no longer rely on the natural resources, but on the primacy sources human resources, the educated personnel capable of responding to the challenges very quickly. Several speakers in various seminars, discussions or writings in the media suggests that, overall, the quality of Indonesian human resources still lag behind that human resources developed countries and neighboring countries, such as Malaysia and Thailand [1].

This fact is more than enough to encourage experts and practitioners conduct systematic reviews to fix or improve the national education system in order to output the school is able to adapt dynamically to changes and challenges, the government has floated the idea of management education based school (school-based management)that provides ample room for the school and community to determine its own development programs and plans according to the needs and conditions of each [2-7]. In line with the idea of decentralized management of education, school management functions need to be empowered to the maximum in order to work effectively to produce quality graduates who are expected by society and the nation [8].

Implementation of these ideas need to be supported by a set of instruments that will encourage schools to work to improve the effectiveness of its management functions continuously so as to develop into a learning organization $[9,10]$. Effective school assessment models (junior level) consisting of instruments and procedures that can be used by educational managers to assess the success of the school [11]. The assessment results can then be taken into consideration to make school improvement efforts [12].

Received: April 8, 2019

Reviewed: June 19, 2019

Accepted: July 23, 2019 
This study aims to develop a model assessment consists of instruments and guidelines for implementation. In the long term, the quality of effective school appraisal expected to spur each school to conduct assessments (self-evaluation) and made the repairs needed on a regular basis to improve the effectiveness of its management functions, so as to make every school is expected to produce quality graduates. More specifically, this study also aims to develop: (1) construct and effective school indicators, (2) a set of effective school assessment instruments, (3) an effective system of school assessment and implementation guidelines (including the interpretation of the results) [13-15].

\section{RESULTS AND DISCUSSION}

School effective according to Prince George's County Public Schools is a school that all resources are organized and utilized to ensure that all students, regardless of race, gender, or socioeconomic status, can learn the curriculum materials that are essential in the school. The formulation of this notion is more oriented to the optimization of education goals as contained in the curriculum [16].

Another understanding about effective school proposed by Cheng in [17], which is an effective school shows in the school's ability to function optimally, both the function of economic, social and humanitarian functions, political functions, cultural functions and educational function. Economic function is to give school supplies to students in order to generate economic activity so that it can prosper. The social function of the school is humanity as a medium for students to adapt to people's lives. Political function of the school is as a vehicle to acquire knowledge about the rights and obligations as citizens. The function of culture is a medium for the transmission and transformation of culture. The function of education is the school as a vehicle for the maturing process and the formation of the personality of students.

These functions there are the common functions (notice function), in the sense that applies to all types and / or levels of schooling, and some are more prominent on the types of a particular school (distinctive function), such as in schools that have religious characteristics, vocational schools, or other school types $[15,18]$. Therefore, effective word itself implies about the degree of achievement of the objectives set, then the formulation efforts constructs and indicators of school effectiveness cannot be separated from the concept of ability (competence) which will be developed through education in schools.

Schools in Indonesia was developed to help students master the competencies that are useful for life in the future, namely: (a) the competence of religion, include knowledge, attitude and skills of religious needed to be able to perform the function of man as a servant of Allah Almighty in everyday life, (b) academic competence, including knowledge, attitudes, abilities, and skills necessary to be able to follow the development of science and technology in accordance with the level of education, (c) the competence of the economy, including the knowledge, attitudes, and skills necessary to meet the needs of the economy that can live well in the community, and (d) personal social competence, including knowledge, system of values, attitudes and skills to be able to live adaptive as citizens and residents of the international democratic community [19, 20].

School education as an integrated system consisting of a number of components that depend on each other. Thus, the development of competence on students cannot be left only to the teaching and learning activities (KBM) in the classroom, but also on climate and cultural life of the school as a whole. Each school as a whole is expected to provide a learning experience for all students to master the competencies in the top four in accordance with the level of education and special mission assigned.

Theoretically, the assessment of school effectiveness need to be made by reviewing how the whole school components interact with each other in an integrated manner in support of the four competencies that must be mastered by students [21, 22]. In practice, 
the holistic view is difficult to implement completely due to limitations of assessment approaches that can be used. Therefore, the notion of effective school assessment is defined as an assessment of the optimal functioning of each component of school in favor of mastering competencies that must be mastered by students [23].

The essence is contained in the introduction above is a function of the school as a place of learning that has an obligation to hold a quality learning experience for learners. That is the essence of the mission or the basic tasks of the school, which should be the basis for learners and effective analysis of school performance. Effective schools can be defined as schools that show the level of performance expected in organizing the learning process, by showing the quality of learning outcomes to the learners in accordance with their main duty. The quality of teaching and learning are satisfactory result is an accumulative product of all school services performed and the influence of the atmosphere / climate conducive created in the school. Various perspectives can be recounted below.

Effective school in Organisms Theory Perspective is Schools are able to realize what is called a self-renewing schools or adaptive schools", also called as a learning organization" is a condition in which the school as an institution the entity is able to deal with the problems it faces while demonstrating its capabilities to innovate [24]. According to the theory of the organism, the world is not an inanimate object, but an energy that has the capacity to change to adapt to the environment. In this perspective, any form of life will only be able to survive if the organism is capable of responding appropriately to adapt to the changes that occur in the vicinity. These conditions apply to the school, where Garmston and Wellman referred to it as the Adaptive Organism. To be adaptive, school as an organization must continuously question the two things that are essential, namely: (1) What is the nature of the existence of the school? and (2) What is the main goal? The development of effective school indicators can be seen in the Table I below.

Table I. Indicators of School Effectiveness

\begin{tabular}{|l|l|}
\hline \multicolumn{1}{|c|}{ Component } & \multicolumn{1}{c|}{ Indicators } \\
\hline $\begin{array}{l}\text { School goal is stated clearly } \\
\text { and specifically }\end{array}$ & $\begin{array}{l}\text { School goal: } \\
\text { 1. Indicated clearly } \\
\text { 2. Used for decision-making } \\
\text { is understood by students, teachers, and staff }\end{array}$ \\
\hline $\begin{array}{l}\text { Leadership strong education } \\
\text { by Principal }\end{array}$ & $\begin{array}{l}\text { Principal: } \\
\text { 1. Can be reached easily } \\
\text { 2. Be responsive to the teacher, staff, and students } \\
\text { 3. Responsive to parents and the community } \\
\text { 4. Implement leadership focused on learning } \\
\text { 5. Keeping the ratio between teachers / students according } \\
\text { to the ideal ratio }\end{array}$ \\
\hline $\begin{array}{l}\text { Expectations of teachers and } \\
\text { high staff }\end{array}$ & $\begin{array}{l}\text { Teachers and educators: } \\
\text { 6. Are you sure that all students can learn and excel }\end{array}$ \\
7. Academic accomplished results and non-academic \\
8. The teacher's role is important for success of students
\end{tabular}




\begin{tabular}{|l|l|}
\hline $\begin{array}{l}\text { Existence of a positive } \\
\text { climate conducive to the } \\
\text { students to learn }\end{array}$ & 1. Neat, clean, and safe physically \\
& 2. maintained in both \\
3. awards to outstanding & 4. strengthening of the positive behavior of students \\
Students: & 1.Obey the rules of the school and local governments \\
2. Running tasks / timely obligation \\
Teacher: \\
1. Feedback is rapid (immediate) \\
2. Optimally participate in classroom \\
3. Quality of learning assessment \\
4.Helps formulate and implement school development \\
objectives \\
5. Demonstrate professionalism in work \\
\end{tabular}

World Bank in [25], in its report on the experience in conducting Education Quality Improvement Program in Cambodia, identifies four groups of characteristics of effective schools, namely: (1) Supporting inputs which include the support of parents and the community, learning environment that is healthy, effective support from education system, as well as the completeness of books and learning resources are adequate; (2) Enabling condition that includes the effective leadership of competent teachers, as well as the flexibility and autonomy in school a long time; (3) School climate that includes high expectations of students, positive teacher attitude, order and discipline, the curriculum is organized. A system of rewards and incentives for students and teachers, as well as the demands of high learning time; and (4) Teaching-learning process that includes varied teaching strategies, frequent homework, assessments and frequent feedback, and participation (attendance, completion of studies, the continuation of studies) [20, 26, 27].

Based on these studies can be formulated constructs about effective schools for used as a conceptual basis in the pouring indicators of effective schools. Referring to the expected outcomes of school assessment model development activities effectively taken some steps [28].

The steps include: (a) the development of effective schools construct and instruments, (b) develop effective school assessment system, (c) develop guidelines for the effective implementation of school assessment [29, 30]. Visualization of development models based on the procedure developed in this activity can be seen in Figure 1. 


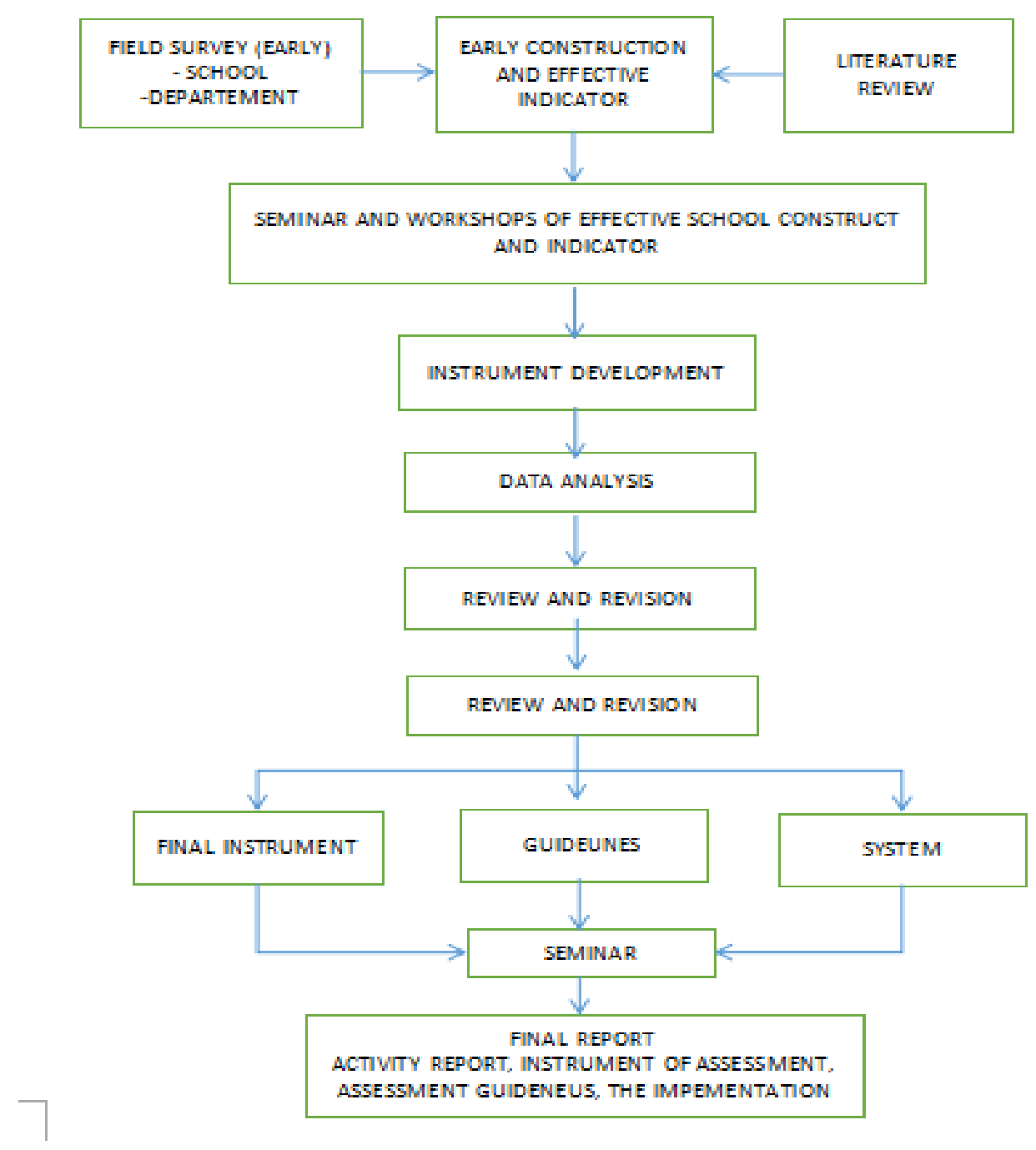

Fig. 1 Assessment model for effective schools

To produce formulation construct effective schools that will be the foundation to develop the instrument made some steps activity. Activities performed a blend of conceptual studies with field surveys for the next seminar by inviting several experts. Formulation constructs have been tested subsequently translated into several indicators to then be used as ingredients in making lattice.

By visual comparison of the percentage of effectiveness for each service between the favorite school and non-favorite school can be seen in Table II.

Table II. Test Results Different Instruments

\begin{tabular}{|c|l|c|c|l|}
\hline No. & \multicolumn{1}{|c|}{ Component } & $\begin{array}{c}\text { The average value of } \\
\text { Every School Favorites }\end{array}$ & $\begin{array}{c}\text { Average value } \\
\text { Every School Non } \\
\text { favorites }\end{array}$ & Different test \\
\hline 1. & Learning & 45.33 & 39.96 & Unlike \\
\hline 2. & $\begin{array}{l}\text { Management of school } \\
\text { climate and }\end{array}$ & 47.02 & 42.27 & Contrast \\
\hline 3. & Guidance and counseling & 42.65 & 35.04 & Unlike \\
\hline 4. & $\begin{array}{l}\text { Student and extra- } \\
\text { curricular }\end{array}$ & 36.33 & 30.70 & Unlike \\
\hline 5. & $\begin{array}{l}\text { Partnerships with } \\
\text { communities }\end{array}$ & 30.92 & 24.42 & Different \\
\hline
\end{tabular}


To standardize the results of different test each service, scores obtained in the Table II above is then created percentage effectiveness of each service with the formula average score of each service is divided ideal score multiplied by $100 \%$. From the calculation result of the formula as in the following Table III.

Table III. Percentage of Effectiveness between Favorite School (F) and Non-Favorite School (NF) Service

\begin{tabular}{|c|c|c|c|c|c|}
\hline No. & Service & School type & $\begin{array}{l}\text { Acquisition } \\
\text { Score }\end{array}$ & $\begin{array}{l}\text { Score } \\
\text { Ideal }\end{array}$ & $\begin{array}{c}\text { Percentage } \\
\text { Effectiveness }\end{array}$ \\
\hline \multirow[t]{2}{*}{1.} & \multirow[t]{2}{*}{ Learning } & $\bar{F}$ & 45.33 & \multirow[t]{2}{*}{62.67} & $72.33 \%$ \\
\hline & & $\mathrm{NF}$ & 39.96 & & $63.38 \%$ \\
\hline \multirow[t]{2}{*}{2.} & \multirow{2}{*}{$\begin{array}{l}\text { Management School and } \\
\text { the school climate }\end{array}$} & $\bar{F}$ & 47.02 & \multirow[t]{2}{*}{62.67} & $75.04 \%$ \\
\hline & & $\mathrm{NF}$ & 42.27 & & $67.38 \%$ \\
\hline \multirow[t]{2}{*}{3.} & \multirow[t]{2}{*}{ Guidance and Counseling } & $\mathrm{F}$ & 42.65 & \multirow[t]{2}{*}{57} & $74.82 \%$ \\
\hline & & $\mathrm{NF}$ & 35.04 & & $61.49 \%$ \\
\hline \multirow[t]{2}{*}{4.} & \multirow{2}{*}{$\begin{array}{l}\text { Extra-curricular Student } \\
\text { and }\end{array}$} & $\mathrm{F}$ & 36.33 & \multirow[t]{2}{*}{57.33} & $63.34 \%$ \\
\hline & & $\overline{\mathrm{NF}}$ & 30.70 & & 53.55 \\
\hline \multirow[t]{2}{*}{5.} & \multirow{2}{*}{$\begin{array}{l}\text { School Partnership with } \\
\text { community }\end{array}$} & $\mathrm{F}$ & 30.92 & \multirow[t]{2}{*}{39} & $79.28 \%$ \\
\hline & & $\overline{\mathrm{NF}}$ & 24.42 & & $62.62 \%$ \\
\hline
\end{tabular}

Educational effective implementation guidelines load ratings on several matters relating to the implementation of the assessment as follows: (1) the purpose of school assessment effective and focused assessment; (2) A description of the instruments used to assess service-learning, management and school climate, guidance and counseling, student affairs and extra-curricular activities, and partnerships with the community; and (3) procedures of evaluation, preparation, execution, processing, interpretation and utilization of assessment results [31].

The rationale outlined earlier about the importance of school assessment for the development of school programs and plans must comply with the requirements and conditions of the school. Objectives and results to be achieved by the school was to assess the effectiveness of the optimization of each function that is run by the school as a place of learning [32]. The assessment results are expected to be used for the benefit of schools (principals and teachers) and outsiders are assessed for improvement, for example the Department of Education school district / city level, province and community effective [33].

The scope and type of assessment instruments include service-learning, management and school climate, guidance and counseling, student affairs and extracurricular and partnership with the community. The assessment instruments include a questionnaire to the principal, vice principal of student / teacher coaching the student, subject teachers, mentor teachers, students and for parents. Other instruments such as observation and interviews used by parties outside the school to support the assessment that has been done by outsider school.

The implementation strategy outlined vote on the implementing organization assessment, implementation time, measures assessment activities began preparation, implementation, data analysis and reporting. Implementation involves assessment financing that includes allocation of votes needed for each implementation of assessment in a school as well as funding sources.

This service form should be given to students who have the function as a place for learning for school students need to provide learning services, service management and school climate, guidance and counseling services, student services and extracurricular activities, as well as partnerships with community service. The instruments are structured to assess each service given to subjects who exercised one service function, but it is also given to other respondents who act as bosses, peers, and the feel and experience the 
service. Thus, it is expected to emerge assessments are subjective and objective then will be a consideration in determining the final score of a particular service [27].

By paying attention to a wide range of services and respondents who answered these services, formulated a formula that can be used as the value of the level of effectiveness of a school. This formula was formulated in the Guidelines for Effective School Assessment [26]. These guidelines can be utilized area in order to support the spirit of regional autonomy and policies to implement school-based management systems.

If the managers of education is to manage their own demands in their respective schools, the assessment of the effectiveness of the school is very fundamental to determine the achievement of each service[34]. These results can provide a basis for improvement in each service in achieving the expected targets in accordance with existing conditions. The results of consideration of the academics involved in seminars and workshops as well as validation of the practitioners and the use of a service, the instrument is composed is an instrument that deserves to be used along with the Guidelines for Effective School Assessment and the proposed development of a model implementation.

\section{CONCLUSION}

Based on the results of field trials, a set of instruments and procedures can be used as a standard in the implementation of the increase in the functions of the school both concerning learning services, service management and school climate, guidance and counseling services, services student and extracurricular and service partnerships with the community. Thus, assessment models need to be disseminated to schools and institutions to be implemented in accordance with its purpose.

Dissemination need good models through the evaluation approach (self / internal evaluation) by the school or by outside parties. To be an effective school assessment in effective and efficient manner can be done by the school, it needs to be institutionalized Effective Educational Appraisal Committee which contains elements of local governments, administrators, school staff, community, universities and experts [35].

\section{ACKNOWLEDGEMENT}

This work is supported by the PT. Media Sinar Utama Purworejo Jawa Tengah Indonesia, IKIP PGRI Wates Yogyakarta Indonesia, PPPPTK Seni dan Budaya Yogyakarta Indonesia and Graduate Program Research and Evaluation of Education Yogyakarta State University, Indonesia.

\section{REFERENCES}

[1] Schweinberger, K., "Effects of feedback on process features of school quality: A longitudinal study on teachers' reception of school inspection of Swiss compulsory schools", Studies in Educational Evaluation, 55, (2017): 75-82.

[2] Chandukala, S.R., J.P. Dotson, and Q. Liu, "An Assessment of When, Where and Under What Conditions In-Store Sampling is Most Effective", Journal of Retailing, 93(4), (2017): 493-506.

[3] Conley, S., D.E. Muncey, and S. You, "Standards-based evaluation and teacher career satisfaction: A structural equation modeling analysis". Journal of Personnel Evaluation in Education, 18(1), (2005): 3965.

[4] Aghabozorgi, S., "An approachable analytical study on big educational data mining". International Conference on Computational Science and Its Applications, (2014): 721-737.

[5] Dutt, A., M.A. Ismail, and T. Herawan, "A Systematic Review on Educational Data Mining". IEEE Access, (2017).

[6] Suhirman, S., "Data Mining for Education Decision Support: A Review". International Journal of Emerging Technologies in Learning (iJET), 9(6), (2014): 4-19.

[7] Abdullah, Z., "Mining significant association rules from educational data using critical relative support approach". Procedia-Social and Behavioral Sciences, 28, (2011): 97-101.

[8] Brighouse, Tim, and David Woods. How to improve your school. Routledge, (2005). 
[9] Hagenson, Lara, and Kathryn Castle, "The integration of technology into teaching by university college of education faculty", Society for Information Technology \& Teacher Education International Conference. Association for the Advancement of Computing in Education (AACE), (2003).

[10] Kyriazi, T., "Using technology to introduce frequent assessments for effective learning: Registering student perceptions", Procedia-Social and Behavioral Sciences,197, (2015): 570-576.

[11] Franklin, N. and P. Melville, "Competency assessment tools: An exploration of the pedagogical issues facing competency assessment for nurses in the clinical environment", Collegian, 22(1), (2015): 25-31.

[12] Brookhart, S.M. and A.J. Nitko, "Assessment and grading in classrooms", Prentice Hall, (2008).

[13] Döş, İ., "Some Model Suggestions for Measuring Effective Schools", Procedia-Social and Behavioral Sciences, 116, (2014): 1454-1458.

[14] Dunham, Jack, "Developing effective school management", Routledge, (2003).

[15] Lee, K.W., D.H. Kim, and H.K. Lee, "Is the Meister Vocational High School more cost-effective?", International Journal of Educational Development, 51, (2016): 84-95.

[16] Taylor, Barbara O., "Case Studies in Effective Schools Research", (1990).

[17] Cheong Cheng, Y., "Teacher leadership style: A classroom-level study", Journal of Educational Administration, 32(3), (1994): 54-71.

[18] Reyes-Garcia, V., "Schooling, Local Knowledge and Working Memory", PLoS One, (2016).

[19] Wang, T.-Y. and F.-J. Hsieh, "Taiwanese high school students' perspectives on effective mathematics teaching behaviors", Studies in Educational Evaluation, 55, (2017): 35-45.

[20] Pedder, D., "School Policies and Practices to Support Effective Classroom Assessment for Learning".

[21] Bartram, D. and R.A. Roe, "Definition and Assessment of Competences in the Context of the European Diploma in Psychology", European psychologist, 10(2), (2005): 93.

[22] Badrun, K. and D. Mardapi, "Pelatihan Pengembangan Penilaian Hasil Belajar pada Implementasi Kurikulum 2013 bagi Guru SMPN 3 Wonosari Kabupaten Gunung Kidul", LPPM Universitas Negeri Yogyakarta, (2014)

[23] Tola, B., "Effective School Evaluation Model: A Development Study", Journalof Modern Education Review, (2014): 679.

[24] Zvoch, K. and M. C. Robertson, "Multivariate summer school effects", Studies in Educational Evaluation, (2017): 145-152.

[25] Bank, W., "Indonesia: Education in Indonesia, from Crisis to Recovery". Washington, DC: World Bank, (1998).

[26] Meiboudi, H., "Creating an integrative assessment system for green schools in Iran". Journal of Cleaner Production, 119, (2016): 236-246.

[27] Murgatroyd, Stephen J., and Colin Morgan, "Total quality management and the school", Open University, (1993).

[28] Blake, A. and J. McNally, "Becoming an Effective Science Teacher".

[29] Derqui, B. and V. Fernandez, "The opportunity of tracking food waste in school canteens: Guidelines for self-assessment", Waste Management, 69, (2017): 431-444.

[30] Jónsson, Í. R., K. Smith, and G. Geirsdóttir, "Shared language of feedback and assessment. Perception of teachers and students in three Icelandic secondary schools", Studies in Educational Evaluation, 56, (2018): 52-58.

[31] Satori, D., "Masalah Mutu Pendidikan", Makalah bahan diskusi pendidikan bersama Kepala Sekolah dan Guru-guru di YP-PGII pada tanggal, 11, (1995).

[32] Rice, E. H., "The collaboration process in professional development schools: Results of a metaethnography, 1990-1998", Journal of Teacher Education, 53(1), (2002): 55-67.

[33] Malakolunthu, S. and S. K. Hoon, "Teacher perspectives of school-based assessment in a secondary school in Kuala Lumpur", Procedia-Social and Behavioral Sciences, 9, (2010): 1170-1176.

[34] Chryssolouris, G., D. Mavrikios, and L. Rentzos, "The Teaching Factory: A Manufacturing Education Paradigm", Procedia CIRP, 57, (2016): 44-48.

[35] Sando, K.R., "Assessment of SOAP Note Evaluation Tools in Colleges and Schools of Pharmacy", Currents in Pharmacy Teaching and Learning, 1(1), (2017). 